\title{
Perceptions of Career and Technical Education in Montana: How Did $A$ Nation at Risk Effect Workforce Education in the Late $20^{\text {th }}$ Century and Now?
}

Bill Ryan

Correspondence: Bill Ryan, School of Technical and Professional Studies, University of Arkansas- Pulaski Technical College, North Little Rock, Arkansas, United States.

Received: Nov. 3, 2020

doi:10.11114/jets.v9i1.5070
Accepted: Nov. 29, $2020 \quad$ Online Published: Dec. 6, 2020

URL: https://doi.org/10.11114/jets.v9i1.5070

\begin{abstract}
Career and Technical Education provides students of all ages with the academic and technical skills, knowledge, and training necessary to succeed in future careers and to become lifelong learners. It marries educational objectives and workforce skill sets identified by industry as critical and in high demand. Demand for employees with these skill sets are critical, yet employers are having an increasingly hard time filling these positions. Have stigmas and biases created by education policy such as A Nation At Risk, as well as, the resulting education shift from Career and Technical Education as a part of a well-rounded public education to College Preparatory curriculum in high schools created a "four-year or bust" societal norm?
\end{abstract}

Keywords: Career and Technical Education, (CTE), apprenticeship stigmas, biases, workforce, perceptions, vocational education, skills gap, Generation X, Millennials

\section{Introduction}

\subsection{Problem}

Two generations of working-age students were the target sample groups in this research Generation X (born 1965-1980) and Millennials (born 1981-1996), whose secondary education may have been influenced by educational policy shifts resulting such as 1983's Department of Education publication A Nation At Risk, which changed how students prepared for Career and Technical Education. The aim of this research is to identify educational stigmas, trends, or biases within the cultural/social structure in Montana, whereby we may be able to better gauge the impacts of past practice and its continuing effects.

A Nation at Risk was an educational policy statement written in 1983 by the U.S. Department of Education in response to increased market pressure from Japan and Germany in automotive and engineering technology. Toyota's cars were more fuel efficient, affordable, and longer-lasting than the products offered by the big three auto manufacturers in the U.S., in addition, German engineering breakthroughs were a threat to American engineering dominance. A Nation At Risk set a goal to "combat mediocrity in a global marketplace...by creating a Learning Society" (DOE, 1983). This policy saw the solution to regain our global economic dominance was to track young people into traditional 4- year college education with the creation and encouraging of the college prep curriculum track in high schools.

\subsection{Importance of the Problem}

Did this create a problem for Career and Technical Education, in that the college prep curriculum left little room for vocational educational courses by shifting objectives to math, science, and critical thinking? As a result, in February 2000, the National Center for Education Statistics reported that from 1982 to 1994, there was a general decline in the participation of high school students in vocational education. "Because students have been required to take more academic coursework, they may have elected to take fewer vocational courses. Alternatively, because of fiscal or economic pressures, or both, schools may have reduced their vocational offerings in recent years" (U.S Dept. of Education, 2000).

In a recent article written by Chrissy Suttles for the Ellwood City Ledger in Pennsylvania published January, 2020 summarizes the stigmas and successes of Career and Technical Education. "We face this everyday." said David Wytiaz, administrative director for Beaver County Career and Technology Center. "Before we were BCCTC, we were vo-tech, or 'slow tech', where the dumb kids go. We still face that stigma, but I think it's getting better." The author added, “...the 
biases involving trade careers are well-documented. A new online survey commissioned by national metal supplier Metal Supermarkets suggests that people 18 to 24 would rather work at a coffee-shop than a high paying skilled trade." Despite the fact that the average trade school degree costs $\$ 33,000$ compared to a $\$ 127,000$ bachelor's degree, according to the National Center for Education Statistics. In addition, those with trade and technical educations are actually slightly more likely to be employed than their academic peers, according to the U.S. Department of Education.

\subsection{Relevant Scholarship}

Relevant research has been conducted to measure the long lasting effects of A Nation At Risk and federal oversight of education in the U.S., most of this research explores the effects at the 25 year and 30 year anniversaries of $A$ Nation At Risk when first presented for national consumption in 1983, these years include 2008-2016. The impact on Career and Technical Education and workforce training have yet to be explored in detail. It is the hope of this author that this study will begin the conversations which will result in a more thorough understanding of this phenomenon, as the impacts affect local, state, national and global markets.

Scholarly research regarding A Nation at Risk as an education policy and a "call to arms" exists in Mehta's 2015 publication Escaping the Shadow: "A Nation at Risk" and Its Far-Reaching Influence, Burdick's The Legacy of A Nation At Risk (2012), and "A Nation at Risk" and the Blind Men (2008) by Sally Blake. These works share a common theme: a focus on math, reading, and critical thinking in curriculum and increasing academic course work to achieve higher scores on standardized tests neglects other rich learning experiences that comes from the study of art, music, history, science, foreign language, and physical education- all currently being pushed to the periphery or eliminated completely (Scott, 2011, p.276 as cited in Burdick, 2012, pg.4-5) and many states have cut funding for music and the arts in order to maximize time and resources for tested subjects (Mehta, p.25). The author of this paper includes Career and Technical Education and workforce exploration in this category of rich yet still "cut" learning experiences.

Many opinion, editorial, and industry information pieces such as the article referenced above as well as in the discussion section of this paper do support the existence of this skills-gap and workforce shortage issue. In an article for American Radio Works entitled, The Troubled History of Vocational Education, author Emily Hanford states, "By the late 1990s, vocational education had a major image problem. Vocational programs had become a kind of dumping ground for kids who weren't succeeding in the traditional academic environment". Furthermore, "In many school districts, vocational education wasn't much more than a "second- tier special-ed program" says Jim Stone. The perception that vocational education programs are and have been dumping grounds for the helpless, un-educate-able troublemakers has successfully permeated the perceptions and attitude of the U.S. Education system. As a result, CTE is often simply tolerated in secondary education and, in some cases, subjugated as a purgatory for undesirable students.

Career and technical education is an educational strategy for providing young people with the academic, technical, and employability skills and knowledge to pursue postsecondary training or higher education and enter a career field prepared for ongoing learning (ACTE et.al, 2010). Career and Technical Education marries educational objectives and workforce skill sets identified by industry as critical and in high demand, included in these high demand skills are interpersonal communication, writing, quantitative reasoning, and critical thinking. Yet, from a historical context, CTE and vocational education has been stigmatized as "less than" education. Common perceptions include:

- CTE related careers and skill sets not require a high IQ;

- CTE skills-set can be learn by anyone simply by doing them for a while;

- CTE skill sets can be mastered with minimal effort;

- CTE related jobs and careers are menial, and do not require critical thinking ability.

An article called Vocational Education: Perceptions in the U.S. and Abroad, points out, "The unfortunate situation is that many US employers have a negative connotation with vocational education because of its reputation ... and, yet it must not be forgotten that employers need a skilled workforce" (Nkhereanye, 2014).

\subsection{Hypothesis}

Perceptions of Career and Technical Education and related careers are observed, measured and compared among Generation X and Millennials in Montana in a quantitative analysis. The quantitative portion of this project will identify perceptions of Career and Technical Education held by a sample of high school and college students who are preparing to enter the workforce or begin college coursework. The primary objective of this research are:

1. Identify significant statistical differences in high school and college student's perceptions of Career and Technical Education at the secondary and post-secondary levels.

2. Identify significant statistical differences between respondents in regard to gender. 
Hypothesis: Perceptions of Career and Technical Education and related careers are positive in high school, but despite this, post-secondary consideration and entry into Career and Technical Education coursework/training are low.

\section{Method}

\subsection{Participants}

This research was conducted by an anonymous online survey, which was distributed to high schools throughout Montana. During the active survey period, 197 students started the survey and 189 respondents (96\%) participated and completed the survey. The schools ranged in size from class AA high schools (1500 + students), class A (500+/-), class B (200 +/-), and class $\mathrm{C}$ high schools (200 or $>$ ). Only students 18 years of age and older were allowed to participate. This was controlled by the high school instructors who distributed and administered the survey, as well as a qualifying question in the survey to confirm age. In addition, individuals in freshman and sophomore general education courses at local universities were surveyed for post-secondary perceptions and perspective on post-secondary college- coursework.

\subsection{Study Framework}

Demographic data collected consisted of responses to three questions:

1.) What is your gender?

2.) Are you a High School student or College student?

3.) What is your age?

These questions established the baseline data describing the survey population and used to determine if the population is representative of the subject group that will yield the most accurate and current data to measure previous and current generational perceptions of Career and Technical Education and related careers.

Next, questions were asked to identify students who did or did not take or have the opportunity to take Career and Technical Education courses in high school. The answers to these questions were a mix of YES/NO responses, multiplechoice, and Likert scale (1-10) sections.

4.) Did you or are you taking Career and Technical Education related courses in high school?

5.) Were/Are Career and Technical Education courses offered at your school?

Depending upon the answer to question five, respondents either continued to question six or were routed to question 17. If the respondent answered YES to question five, the respondent continued with the following questions...

6.) Which Career and Technical Education track did you take?

7.) Were/Are these courses important to your overall education?

8.) Did you/Do you enjoy Career and Technical Education courses?

9.) Did taking Career and Technical Education courses make you consider a Career and Technical Education related career field?

10.) Did/Do exposure to Career and Technical Education courses in high school influence your decision about postsecondary (after high school) educational choices?

11.) Are you/ did you consider Career and Technical Education related careers?

These questions identify the perceptions of those who were exposed to Career and Technical Education related courses in high school, how many did take and how many did not take Career and Technical Education courses despite them being offered in their high school, and in which of the four Montana Office of Public Instruction (OPI) tracks: Industrial Technology; Agriculture; Family Consumer Science; and Business that the respondents participated.

Questions 12 through 16 are used to quantify the attitude toward Career and Technical Education courses and career fields by respondents who have had exposure to this type of coursework in high school:

12.) What aspects of Career and Technical Education related careers are appealing to you?

13.) Do you feel that Career and Technical Education related professionals are respected in their fields?

14.) Do you feel that Career and Technical related professions are respected among professionals in other career fields?

15.) Which Career and Technical Education related career field are you/did you consider?

16.) What level of training do you expect to acquire to be successful in your Career and Technical Education related career? 
If a respondent answered NO to question 5, the respondent was directed by the survey to questions 17 through 20 . These questions were used to quantify the attitude toward Career and Technical Education courses and career fields by respondents who did not have exposure to this type of coursework in high school. These questions were nearly identical to the questions asked in 12-16, with one modification to question 17 (to make it different from question 12 by adding "not") and leaving out question 15 as it would not apply.

17.) Which of these are not appealing to you about a Career and Technical Education related career?

18.) Do you feel that Career and Technical Education related professionals are respected in their fields?

19.) Do you feel that Career and Technical Education related professionals are respected among professionals in other career fields?

20.) Which would you consider the appropriate level of education or experience that is required to do a Career and Technical Education related career?

All respondents were then directed to question 21 in order to complete the survey. Question 21 through 27 provided baseline information in regard to the general perception of Career and Technical Education related careers as they apply to local economies, salary scale compared to other career fields, where Career and Technical coursework and apprenticeship rank vs. four-year education, and whether there is a negative connotation associate with the names Vocational and Career and Technical Education.

21.) Are Career and Technical Education fields important to the economic fabric of Montana?

22.) Do you consider Career and Technical related careers...menial or meaningful?

23.) Do you consider a four-year degree more important than a two-year Career and Technical Education degree or an apprenticeship as a path to a good career?

24.) Do you feel that anyone can learn a Career and Technical Education related career skill set simply by doing it for a while?

25.) Career and Technical related professions earn less money than four-year degree graduates.

26.) Do you feel that the term "vocational" has a negative connotation?

27.) Do you feel that Career and Technical Education has a negative connotation?

\section{Results and Discussion}

\subsection{Recruitment}

The participating high schools and colleges were recruited through professional networking at educational conferences, visits to high schools, and personal connections to high schools and colleges. This survey was voluntary and no promise of payment or reward was offered to either the participants or the administrators. This survey was active for three weeks in March 2016.

\subsection{Statistics and Data Analysis Baseline}

The first three questions of the survey gathered descriptive data such as gender, attending high school or on college, and the age of the respondent. The survey had more female respondents (113) than male respondents (79). The majority of the respondents were 18-24 years old (153) followed by 25-34 years old (28) with more college students (129) than high school students (62) responding. This survey was widely distributed to many small, medium, and large high schools throughout Montana. One factor for the lower number of respondents identified as high school students is that within the time frame of data collection, some high school seniors are not yet 18 years of age, an Institutional Review Board requirement for this survey. Paired t-tests were conducted looking at question 1- gender differences in questions 21- 27. No significant statistical differences emerged.

Question 2- "Are you a High School or College student?" was two-sample t-tested against the same seven questions (2127) of the survey. Five of the seven questions showed no significant statistical difference but, when comparing questions 2 and 22 a significant statistical difference resulted between high school and college students.

When asked if Career and Technical Education related professions are considered menial or meaningful: $t(104)=-2.09$, $\mathrm{p}=0.039$. High School mean $=7.37$, College mean $=8.02$.

The result indicated that college students perceive that Career and Technical Education related careers are more meaningful career paths than do high school students. The result has many facets; for instance, college students may have had more exposure to Career and Technical Education related careers through college experiences (e.g internships, summer jobs, etc..) or because of college experiences and education realize basic economic principles of production and value. It is encouraging that both groups do not see Career and Technical Education related careers are more meaningful 
than menial as indicated by their mean values.

Another statistically significant difference was revealed between question 2 and question 26, if the term "vocational" has a negative connotation. $t(149)=-2.35, \mathrm{p}=0.020$. High school mean -5.02 , college mean $=5.90$.

This result indicated that high school students perceive that the term "vocational" has less of a negative connotation than college students, and respectively, college students perceive "vocational" to have more negative connotations. Yet, when the same sample groups were asked if the term "Career and Technical Education" has a negative connotation there was no statistically significant difference. This indicates that the term change from "Vocational Education" to "Career and Technical Education" does have an influence on the perception of this type of education.

192 respondents answered Question 4, "Did you/ are you taking CTE courses in High School ?"; 55.73\% reporting took or are taking CTE courses in high school, while $44.27 \%$ are not or did not. This difference helps to provide clear and representative data for the perceptions of Career and Technical Education from the target subject groups. While the same respondents indicated that $83.85 \%$ had Career and Technical Education courses offered and available in their high schools, and $16.15 \%$ did not.

The raw data collected in Question 4 and Question 5 reveals that 54 of 192 respondents ( 28\%) chose not to take Career and Technical Education courses in high school although the courses were offered.

After Question 5 subject groups were divided into Group 1 (having taken or having had the opportunity to take Career and Technical Education courses in high school) and Group 2 (those respondents who did not have the opportunity to take Career and Technical Educational courses in high school.

\subsection{Group 1}

$77 \%$ of respondents reported that they did take or had the opportunity to take Career and Technical Education related coursework in their high school. Subject Group 1 was presented with the four Montana Office of Public Instruction Career and Technical Education course concentrations: Industrial Technology, Family and Consumer Sciences, Business, Agriculture, or they did not take Career and Technical Education options in Question 6.

Of the respondents, $40.79 \%$ reported that they participated in Industrial Technology courses, which is not surprising, as these types of courses are typically very widely offered in secondary education and are most often associated with Career and Technical Education coursework. The second highest response to the question, $22.37 \%$ of respondents did not take Career and Technical Education coursework. This is surprising. When totaled, the remaining Career and Technical Education concentrations (Agriculture; Family Consumer Science; and Business) accounted for $36.84 \%$ of the respondents, we see that among respondents who have the opportunity to take Career and Technical Education courses a total of $77.63 \%$ chose to take Career and Technical Education. Leaving $22.37 \%$ who did not.

Study subjects responded favorably when asked if Career and Technical Education courses were important to their overall high school education (Question 7) with a mean average of 6.90. A 2-sample T-test for statistical significance was performed against Question 4. Unsurprisingly, a significant statistical difference was evident between sample students who did take Career and Technical Education courses and those sample students who did not take Career and Technical Education coursework in high school in regard to whether or not the courses were important to overall high school education, $\mathrm{t}(93)=-4.62, \mathrm{p}=0.00$. Mean averages: Yes- 7.65 , No- 5,43 .

A regression analysis for Question 7 was also performed against Question 9 - Did taking CTE courses make you consider a CTE related career field. $\mathrm{F}(156)=148.8, \mathrm{P}=<0.01, \mathrm{R}^{2}=0.48$. This reveals a relationship between the perceived importance of Career and Technical Education in high school courses when they are taken and then consideration of Career and Technical Education related after high school.

Question 10- Did exposure to Career and Technical Education courses in high school influence your decision about postsecondary educational choices? $\mathrm{F}(156)=169.5, \mathrm{P}<0.01, \mathrm{R}^{2}=0.50$. This shows a relationship between the perceived importance of Career and Technical Education in high school courses when they are taken and influence on postsecondary choices.

Note: the distribution also takes into account the 30 +/- respondents who did not choose to take Career and Technical Education courses in high school. With further investigation, those $30+/-$ respondents can be factored out and their responses compared to the responses of those who did indeed choose to take Career and Technical Education courses.

When asked if they enjoyed Career and Technical courses, responses resulted in an overall mean value of 7.68 for all Group 1 respondents. When this question was 2-sample t-tested against Question 4, an expected result is observed because respondents who did not take Career and Technical Education courses would not be expected to have enjoyed courses they did not take. But, the raw data indicates from the previous question that even if the respondent did not feel the Career and Technical Education course contributed to their overall education, more of the respondents enjoyed the courses then 
did not, $\mathrm{t}(93)=6.89, \mathrm{p}=0.00$. Mean averages: Yes 8.68, No 5.79. Respondents gave a mean value of 5.92 when asked if taking Career and Technical Education related courses made them consider a Career and Technical related career. This represents a drop in the mean average when compared to the respondent's answers when asked if Career and Technical Education courses contributed to their education (Q7) and if they enjoyed the courses (Question 8). This may indicate that even though the respondents valued the education or enjoyed the courses, they still are not considering a Career and Technical related career field.

When Question 9 is a 2-sample t-tested against Question 4, we see a significant statistical difference between the respondents who did take and did not take Career and Technical Education courses and if this made them consider a Career and Technical Education related career, $t(112)=6.35 . \mathrm{p}=0.00$. Mean averages: Yes 6.95, No 3.93. This is an expected difference because respondents who did not take nor had the opportunity to take Career and Technical Education courses would not have Career and Technical Education related courses influence their future career choices. It is an interesting comparison because the statistical data shows a significant perceptional difference but the mean average in the raw data does not reflect the same significant difference with a mean average across both groups.

Question 10 asks a similar question to Question 9 but instead if exposure to Career and Technical Education courses influences post-secondary educational choices. Question 10 had a mean value of 5.95, a similar mean average as Question 9. When tested against Question 4, the result $\mathrm{t}(112)=5.22, \mathrm{p}=0.00$. Mean averages: Yes 6.84, No 4.30, shows a significant statistical difference between the two groups. Like the previous questions, this is an expected result as the respondents who did not take or have the opportunity to take Career and Technical Education would not be expected to have Career and Technical Education influence post-secondary decisions. Question 9 and 10, when viewed together, and 2-sample ttested against Question 4, indicate that between the sample groups who did take or had the opportunity to take Career and Technical Education is significantly different from those in the sample group who did not or did not have Career and Technical Education courses offered in high school.

Yet, when the combined mean averages are compared, Question 9 - 5.92 and Question 10 - 5.95, are slightly positive, this indicates that overall many in the sample group are not considering a Career and Technical Education related career or pursuing post-secondary Career and Technical Educational opportunities.

Question 11 directly answers that question as to whether the respondents considered a Career and Technical Education career. $51.59 \%$ responded NO, they did not or are not considering a Career and Technical Education related career, while 48.41\% did consider a Career and Technical Education related career. Again, these are respondents in subject Group 1 who, for the most part, did take or had the opportunity to take Career and Technical Education courses in high school. There is a similarity between Question 11 and Question 4 - Did you or are you taking CTE courses in high school? Yes, $55.73 \%$, No $44.27 \%$. It seems that after exposure to Career and Technical Education related courses the number of respondents does drop. This group still includes respondents who did have Career and Technical Education courses offered in high school but decided not to take Career and Technical Education courses which have been identified as $\sim 54$ respondents.

Question 11, Did you/Are you considering a Career and Technical related career, was 2-sample t-tested against other Group 1 perception questions Question 7-Question 14, less Question 12 as it is not categorical in nature. All tests resulted in significant statistical differences, except for Q14, which reasons for this are further discussed.

The results of Question 11 vs. Question 7, $\mathrm{t}(143)=7.07, \mathrm{p}=0.00$. Mean average: Yes 8.32, No 5.47, shows a significant statistical difference exists between respondents who felt that Career and Technical Education courses were important to their overall education and the respondents considered a Career and Technical Education related career. This is an expected result. The average mean between the two groups, 6.90, is positive in that this group perceives Career and Technical Education courses as an important component of their high school education.

Question 11 vs Question 8, $\mathrm{t}(123)=6.82, \mathrm{p}=0.00$. Mean average: Yes 8.92, No 6.46. It is not surprising that respondents who enjoy Career and Technical Education courses do consider a Career and Technical Education related career, and those who did not enjoy Career and Technical Education courses do not consider Career and Technical Education related career. This result is expected. But, it is the respondents who identify as enjoying Career and Technical Education courses, but not considering a Career and Technical Education related career, that should be identified and carefully examined. It is this group that may provide more insight into the perceptions of Career and Technical Education careers. Is it stigmas and biases or societal, peer, or parental pressures that play into the decision not to consider a Career and Technical Education related career?

Question 11 vs. Question 9, $\mathrm{t}(154)=12.91, \mathrm{p}=0.00$. Mean averages: Yes 8.23 , No 3.61. While this question seems redundant in nature, it provides statistical data that quantifies and confirms that taking Career and Technical Education courses does have a significant influence on whether the respondents considered a Career and Technical Education related career or did not. It should be pointed out that the standard deviation between the YES and NO respondents and if taking 
Career and Technical Education courses influenced considering a Career and Technical Education career was 2.14 and 2.34 respectively. This reveals that both groups feel very strongly, almost identically, but in polar opposite fashion, about whether taking Career and Technical Education courses influenced the respondents' choice to consider a Career and Technical Education related career or not.

Question 11 vs. Question 10, $\mathrm{t}(152)=9.31, \mathrm{p}=0.00$. Mean average: Yes 7.87, NO 4.06. There is again, a significant statistical difference between the two groups when asked if Career and Technical Education exposure influenced postsecondary choice. This result is expected. As mentioned, this sample group belongs to generations that are programmed to respond only to 4-year educational opportunities nearly all of which do not include preparing for a Career and Technical Education related career.

Question 11 vs. Question 13. $\mathrm{t}(156)=2.49, \mathrm{p}=0.014$. Mean average: Yes 7.71, No 6.84. Q13 asks if Career and Technical Education professionals are respected by other professionals within their career field. Both groups, YES and NO, mean averages provide a positive perception of the respect accorded Career and Technical Education related professionals within the industry. While there is still a significant statistical difference between the two groups, the contrast is balanced when compared to previous questions when asked and compared. Respondents considering a Career and Technical Education related career perceive that Career and Technical Education related careers are highly respected by their respective industrial peers, while respondents who are not considering Career and Technical Education careers feel slightly less positive about the respect within the peer groups. This question was asked to identify if respect and prestige are deciding factors for considering a Career and Technical Education related career. It appears that from this data, perceptions regarding respect within the industry is not a factor when considering a Career and Technical related career or not.

Question 11 vs. Question 14, $\mathrm{t}(156)=1.83, \mathrm{p}=0.069$. Mean average: Yes 7.03, No 6.38. Q14 does not represent a significant statistical difference between YES and NO respondents when asked if they feel that Career and Technical Education professionals are respected by other careers that are considered professional occupations i.e. doctors, lawyers, business professionals, etc. We see from the mean averages that both groups perceive that Career and Technical Education related professions are respected overall. The lack of statistical difference stems from a drop in the mean average from the YES group and an increase in the mean average form the NO group. This is an interesting result. The respondents who consider a Career and Technical Education related career indicate that they perceive there is less respect from professionals outside Career and Technical Education related fields, while respondents not considering Career and Technical related careers perception did decrease, it did not correlate with the decrease from the YES respondents and decreased less, thus closing the significance gap. The combined mean for both groups is 6.71 , indicating that there is a positive perception of Career and Technical Education related careers among other career professionals. This is encouraging, but not a significant factor in why a respondent does or does not consider a Career and Technical Education related career.

Question 13 asked if Career and Technical Education professionals are respected in their fields. Meaning, are they respected among their peers in similar careers, in title, and annual salary. This netted a mean value of 7.29, indicating that the overall respondents strongly feel that there is respect among professionals in these careers for the job.

When this question is tested in a 2-sample t-test against Question 4, the result $\mathrm{t}=(105)=2.22, \mathrm{p}=0.029$. Mean average: Yes 7.71, No 6.84, shows that there is a significant statistical difference between respondents who did take Career and Technical Education courses and those who did not. When asked if Career and Technical Education Professionals are respected among professionals in other career fields (i.e. doctors, lawyers, business professions), Question 14 respondents answered with a mean value of 6.71. This still indicates a positive response to the question but does not garner the same confidence regarding respect among professionals in similar career fields. When Question 14 is a 2-sample t-tested against Question 4, the result $\mathrm{t}(105)=2.40, \mathrm{p}=0.018$. Mean averages: Yes 7.03, No 6.38, show that there is a significant statistical difference between those respondents who did take Career and Technical Education coursework when compared to those respondents who did not.

\subsection{Group 2}

Subject Group 2 are respondents who identified that they did not take, nor had the opportunity to take Career and Technical Education courses in high school. It is possible and plausible that this group, who answered NO to Question 5, Were/Are CTE courses offered at your high school? did indeed attend public or private schools that do not have Career and Technical Education courses as part of their secondary educational curriculum. In this section, the perceptions of respondents who answered NO to Question 5 are compared to respondents who answered YES to Question 5. Many of the questions asked to Group 2 (Question 17-Question 20 in the survey) are very similar to questions asked of Group 2 with small key-word changes appropriate to the question. For example, Group 2 subjects were asked Question 17-Which aspects of CTE careers are not appealing? whereas Group 1 was asked in Question 12 Which aspects are appealing in CTE careers?

Question 18 for Group 2 is the same as Group 1 question 13, in asking are Career and Technical Education related 
professionals are respected in their fields. From Group 2, the mean value attributed to this question is 7.40 . This reveals a positive perception of respect among Career and Technical related professionals. When compared, Group 2 has a slightly more positive response to the question than Group 1 at 7.29. This small difference could infer that students who did take Career and Technical Education courses could already have suffered negative perceptions associated with this career field resulting in a lower mean average or the respondents who did not take Career and Technical Education related courses who are in Group 1 may have influenced the mean average.

Question 19 for Group 2 is similar to Question 14 for Group 1 and asks if Career and Technical professionals are respected by professionals in other career fields not associated with Career and Technical Education. Group 2 respondents gave this a mean value of 6.57. This represents a drop (almost a full point) from Question 18. This group also has a less positive response than Group 1 at 6.71 when asking the same question. What we see from both groups is that while there is a positive perception of the respect afforded Career and Technical Education related professionals between other Career and Technical Education related professionals, this drops when compared to respect levels compared to other professions (i.e. lawyers, doctors, business professionals).

\section{$3.5 \mathrm{All}$}

Questions 21-27 were answered by all respondents to the survey. These questions were 2 sample t-tested against Question 4 (Did you take CTE courses?, Q5 (Were CTE courses offered in high school?), and Question 11 (Did you consider a CTE career?)

Question 21 asks all respondents about their perceptions regarding the importance of Career and Technical Education related professions to Montana's economic fabric. This question netted a mean value of 7.43 , a positive response. When 2-sample t-tested against Question 4 the result shows that there is a significant statistical difference between those respondents who did take Career and Technical Education courses in high school and those who did not, $\mathrm{t}(150)=2.41, \mathrm{p}=0.17$. Mean averages Yes 7.71, No 7.11. Both groups have a positive perception regarding the importance of Career and Technical Education related careers in Montana, the data shows a higher concentration of respondents who did take Career and Technical Education courses valuing the importance more so than the respondents who did not. There is also a broad range of responses on the no group even though there are fewer respondents.

Similarly, when 2-sample t-tested against Question 5, a significant statistical difference exists between those respondents who did have Career and Technical Education courses offered in high school and those respondents who did not, $\mathrm{t}(35)=2.04, \mathrm{p}=0.049$.

Respondents who did take or had exposure to Career and Technical Education related courses feel these careers and skillsets are important contributing factors to the well-being of Montana's economy and commerce more so than those who did not take or have had exposure to Career and Technical Education related courses. It may be assumed that the difference between these groups is the same as in the previous test (Question 4 vs. Question 21) as the distributions appear very similar, the observable difference is that the NO group in Question 5 vs Question 21. And, when 2-sample t-tested against $\mathrm{Q} 11$, (Did you consider a CTE related career?), the result $\mathrm{t}(154)=1.54, \mathrm{p}=0.126$. Mean averages: Yes 7.75, No 7.37. There is not a significant statistical difference between the two response groups, Yes and No in this regard.

Question 22 asked respondents if they considered Career and Technical Education related careers menial or meaningful. Because this is an anonymous survey, it is the hope that respondents are honest about how they really feel about these types of careers. This question received a combined 7.83 mean value among all respondents. This represents a positive perception of these skill-sets and careers as meaningful professional careers that have value and a level of respect. When this question was 2-sample t-tested against Question 4, it is revealed that there is not a significant statistical difference $\mathrm{t}=(165)=1.78, \mathrm{p}=0.77$ between those respondents who did take Career and Technical Education and those who did not. But, when 2-sample t-tested against Question 5, a significant statistical difference does exist, $\mathrm{t}=(39)=2.11, \mathrm{p}=0.042$. The respondents who did not have exposure to Career and Technical Education courses in high school perceive these careers differently. As we learned previously, there is a significant statistical difference between those who consider a Career and Technical Education career and those who do not. These results suggest that simply having Career and Technical Education courses in high school influences perceptions regarding the value placed in Career and Technical Education related careers.

Question 23 netted a mean value of 6.25 when asked if a four-year degree is more important than a two-year degree or apprenticeship as a path to a good career. This result has an above-average positive response. The highest response rate from agree to definitely yes, 113 of 184 respondents, feel that a 4-year degree is more important than a 2-year degree and apprenticeship. When 2-sample t-tested against Question 4 no statistical difference is observed, $t(171)=1.34, p=0.182$. Mean average: Yes 6.55, No 5.96.

Question 24 asked if respondents felt that anyone can learn a Career and Technical Education related profession just by 
doing it for a while, this received a mean value of 6.37. This represents a positive response and indicated that respondents feel that by experiencing the skill-set by doing this for a certain duration of time, one can learn the career skill set. It should be pointed out that this question was not asked with an additional description such as "under the guidance of a professional" which would be a structure similar to an apprenticeship. It was asked generally, to provide the best-unbiased answer, which in this case, reveals that the respondents do indeed feel that a Career and Technical Education related profession, in general terms, can be learned by doing without any formal or structured training. When 2-sample t-tested there was no significant statistical differences between Group 1 and Group 2: Question $2=\mathfrak{t}(133)=-0.23, p=0.821$; Question 4=t(171) $=1.34, \mathrm{p}=0.182 ; \mathrm{Q} 5=(36)=0.60, \mathrm{p}=0.554$; Question $11=\mathrm{t}(155) 0.67, \mathrm{p}=0.551$. No statistical significance is observed.

When asked if Career and Technical Education related professionals earn less money than graduates of four-year college graduates in Question 25, respondents gave a mean value of 5.70. This is either encouraging, in that, the respondents understand that a good living can be made in these careers, or it may be discouraging, in that, these two generations may not have a firm understanding when it comes to the salaries and wages associated with either Career and Technical Education related professionals or most four-year degree graduates. The 2-sample t-tests show no significant difference between the groups tested: Question $2=\mathrm{t}(134)=0.44, \mathrm{p}=0.661$; Question $4=\mathrm{t}(174)=-0.02, \mathrm{p}=0.998$; Question $5=\mathrm{t}(38)=$ $-0.37, \mathrm{p}=0.771$; Question $11=\mathrm{t}(153)=0.24, \mathrm{p}=0.551$. Mean average: Yes 5.88, No 5.79.

It must be understood that there are many salary ranges applied to four-year degree graduates, and these salaries depend upon current market conditions and discipline majors. The intent of the question is to measure the general perception that a four-year degree required career pays more than a Career and Technical Education related career. The results show that there is no significant statistical difference in the perceptions of the groups tested. For the purpose of this survey, the question was presented generally to explore if an overall perception that Career and Technical related careers are lowerpaying. The results of these tests indicate that there is not a perception that Career and Technical Education related careers pay less than careers requiring four-year degrees.

Question 26 asked respondents if the term "vocational" has a negative connotation. The mean value given is 5.59. This indicates that the term holds no or a very slightly negative connotation. When 2-sample t-tested against Question 2 a significant statistical difference does exist between the groups, $\mathrm{t}(149)=-2.35, \mathrm{p}=0.020$, HS mean 5.02, College mean 5.90. It is observed that college students attribute a negative connotation to the term vocational more so than high school students surveyed. Most of the respondents answered 5, which indicates indifference to whether the term does have a negative connotation, or the respondents may not recognize the term vocational, as it preceded Career and Technical Education, and therefore, the term may predate the Millennial generation of respondents.

The final question of the survey Question 27 asked if the term Career and Technical Education has a negative connotation. This question has a mean value of 4.67 just under the median value of 5, indicating that Career and Technical Education holds a slightly positive connotation. The highest number of responses (29) are there is definitely not a negative connotation, while the second highest is the neutral median answer of 5 . The 2-sample t-test among the groups show no significant difference between the groups tested: Question $2=\mathrm{t}(124)=-0.63, \mathrm{p}=0.528$; Question $4=\mathrm{t}(178)=0.46, \mathrm{p}=0.644$; Question 5 $=\mathrm{t}(38)=-0.30, \mathrm{p}=0.761$; Question $11=\mathrm{t}(154)=-0.87, \mathrm{p}==0.387$. Mean average: Yes 4.46, No 4.83.

\section{Conclusion}

This research did identify significant statistical differences in the perceptions between different groups of respondents who participated in the survey:

1. Identify significant statistical differences in high school and college student's perceptions of Career and Technical Education at the secondary and post-secondary levels.

Differences between high school and college students are revealed in Q22-Did you consider Career and Technical Education related careers menial or meaningful? In the result and discussion, it is observed that exposure to, experience in, and access to Career and Technical Education courses do influence perceptions between the respondent groups. Other than these two questions, no significant statistical difference exists between high school and college students regarding their perceptions of Career and Technical Education careers, this is expected, and can be viewed as for better or for worse scenario depending upon how you view the problem. For better, there are common perceptions shared between high school and college students regarding Career and Technical Education and related careers, so with the proper marketing strategy, targeted at students at the critical point in life in regard to life-long decisions, we could change the perceptions identified as negative into positives this limiting the societal, peer, and parental bias toward Career and Technical Education related careers. For worse, do we have time to identify and influence change in the negative perceptions of Career and Technical Education and related careers? We must change the perceptions that we know not to be true in order to ensure that much needed industrial, construction and agriculture jobs have qualified workers to fill positions. Or, should industry look to another means in order to fill open positions because stigmas are too entrenched in societal, peer, and 
parental bias to overcome within the timeframe of a generation? As Amy King writes"...as our baby boomers prepare for retirement... Millennials are expected to make up 75 percent of the workforce by $2025 "$ (2016).

2. Identify significant statistical differences between respondents in regard to gender.

Interestingly, no significant statistical differences are observed in regard to gender and perceptions of Career and Technical Education or related careers. This is a good result, it indicates that Career and Technical Education and related careers are not gender-biased and are perceived as gender-neutral. This is important given the need for Career and Technical Education related skill sets required to fill much-needed industry positions. The ability of the industry to hire all trained and qualified workers regardless of gender will increase the likelihood that positions will be filled. In an article written by Shannon Winslow-Claunch (2016) she identifies that:

In 2014, the Bureau of Labor Statistics reported that 9.8 million people worked in the construction industry, of which, only 872,000 were women...while women still face unique challenges in the industry today's construction projects have evolved to become safer and less labor-intensive because of automation, OSHA safety standards, EOC mandates and changing cultural norms, which make working conditions more favorable for women than in the past. Women are also well-suited for crafts such as instrumentation, welding, and electrical because they have superior hand-eye coordination.

Closing the gender gap is one less hurdle for industries who rely on Career and Technical Education related skill sets must jump to recruit qualified workers.

1. Career and Technical Education courses when offered influenced post-secondary decisions.

When testing the result against whether respondents took Career and Technical Education courses in high school or did not (Question 4), significant statistical differences are observed. These differences are observed between the sample groups in Questions 7, 8, 9, \& 10. The questions included, Did you enjoy Career and Technical Education courses, and Did Career and Technical Education courses influence post-secondary decisions? When reviewing the raw and statistical data in the discussion section, it should not surprise anyone that the sample group who did not choose Career and Technical Education courses would not have enjoyed or have been influenced by Career and Technical Education in making a postsecondary decision. The mean averages tell the story as to the impact of having Career and Technical Education as a part of high school education when influencing decisions about a respondents' future. The take-away is that experiencing Career and Technical Education does have an influence on decisions and perceptions when making choices regarding future careers. Other differences observed in the sample groups are the perceptions of Career and Technical Education related professions respected by other professions and significant differences are observed when asked if Career and Technical Education related careers are important to the economic fabric of Montana.

2. Career and Technical Education exposure in high school and taking or not taking Career and Technical Education courses when offered influence post-secondary decisions and perceptions.

Sample group 2 who did not have Career and Technical Education courses offered in high school, identified in Question 5, also perceive certain aspects of Career and Technical Education differently than those that did have Career and Technical Education offered in high school. This does not assume that all respondents who had the opportunity to take Career and Technical Education did so (these respondents are captured in Question 4). For instance, Question 5 NO respondents differ in perception about Career and Technical Education related careers and importance in Montana's economic fabric, as well as, are Career and Technical Education related careers menial or meaningful. These differences are expected, understood, and appreciated as they provide valuable perceptual data. Yet, there is no significant difference between the sample group 1 and 2 in Question 4 and Question 5 when asked if a 4-year degree is more important than a 2-year college education or apprenticeship as a path to a good career; or, can anyone simply learn a Career and Technical Education skill set by doing it for a while; and, Career and Technical Education professions earn less than careers requiring four-year degrees. It is observed that exposure to, experience in, or access to Career and Technical Education related courses does not influence perceptions in all aspects when it comes to perceptions of Career and Technical Education related careers. The "4-year or bust" mentality dominates among all respondent groups and is reflected in these results. Thus reinforcing the perception and stigmas associated with Career and Technical Education related courses and careers.

3. The perceptions of Career and Technical Education/careers are positive, but despite this, consideration of Career and Technical Education coursework/training or careers are low.

The data gathered shows that overall respondents who did participate in Career and Technical Education courses in high school develop appreciation for Career and Technical Education and related careers. Respondents who did participate in Career and Technical Education courses consider Career and Technical Education: an important part of their education (Question 7) and enjoy the courses (Question 8) resulting in a positive mean average, yet when asked if considering a Career and Technical Education related career (Question 9), and Career and Technical Education courses influenced post- 
secondary decisions (Question 10) the mean averages drop a full mean average point. Then, when put to the question: Did you consider a Career and Technical Education career field? We observe more NO answers than YES answers. Going back to examining the raw data in Question 4 and Question 5, we see 54 respondents in Group 1 that chose not to take Career and Technical Education courses in high school although it was offered. When these 54 are factored out of the total no answers of 81, we get 27 respondents who most likely took Career and Technical Education in high school but the experience did not influence them to consider a Career and Technical Education related career. This breakdown of raw data reveals that $74 \%$ of respondents who did take Career and Technical Education courses did consider Career and Technical Education related careers and 26\% of respondents who did take Career and Technical Education courses did not. This is encouraging. It shows that participation in Career and Technical Education courses does influence perceptions of Career and Technical Education related careers enough to make the respondent at least consider a career in these fields.

\section{References}

Association for Career and Technical Education. (n.d.). Carl Perkins Act implementation. Retrieved from http://www.acteonline.org/general.aspx?id=687\#plans

Blake S. (2008). "A Nation at Risk" and the Blind Men. Phi Delta Kappan, 89(8), 601-602. https://doi.org/10.1177/003172170808900814

Burdick, J. (2012). The Legacy of “A Nation at Risk” ERIC online submission

Hanford, E. (2014). The troubled history of vocational education. American Radio Works. Retrieved from http://www.americanradioworks.org/segments/the-troubled-history-of-vocational-education/

King, A. (2016, Fall/Winter). The Future of Workforce Development Starts Now. The Cornerstone. 24.

Mehta, J. (2015). Escaping the Shadow: “A Nation at Risk” and Its Far Reaching Influence. American Educator, 39(2), 20-26.

Nkhereanye, N. (2014, March 5). Vocational Education: Perceptions in the U.S. and Abroad. Retrieved from http://www.classbase.com/News/Vocational-Education-Perceptions-in-the- US-and-Abroad-179.

Scott T. (2011). A Nation at Risk to Win the Future: The State of Public Education in the U.S. Journal for Critical Education Policy Studies, 9(1), 267-316.

Suttles, C. (January 12, 2020). We face this everyday: Skilled trades still stigmatized among young adults. The Times online Retrieved from: https://www.timesonline.com/news/20200112/we-face-this-every-day-skilled-trades-stillstigmatized-among-young-adults

U.S. Department of Education, National Center for Education Statistics. Vocational Education in the United States: Toward the Year 2000. NCES 2000-029 by Karen Levesque, Doug Lauen, Peter Teitelbaum, Martha Alt, and Sally Libera. Project officer: Dawn Nelson.

U.S. Department of Education. (1983, April). A Nation at Risk: The Imperative for Educational Reform. Retrieved from https://www2.ed.gov/pubs/NatAtRisk/risk.html

Washington D. C. (2000). Retrieved from http://www.nces.edu.goc/pubsearch/index.asp

Winslow-Claunch, S. (2016, Fall/Winter). Female Veterans Fill the Gap for Trained Pipefitters. The Cornerstone. 18.

\section{Copyrights}

Copyright for this article is retained by the author(s), with first publication rights granted to the journal.

This is an open-access article distributed under the terms and conditions of the Creative Commons Attribution license which permits unrestricted use, distribution, and reproduction in any medium, provided the original work is properly cited. 